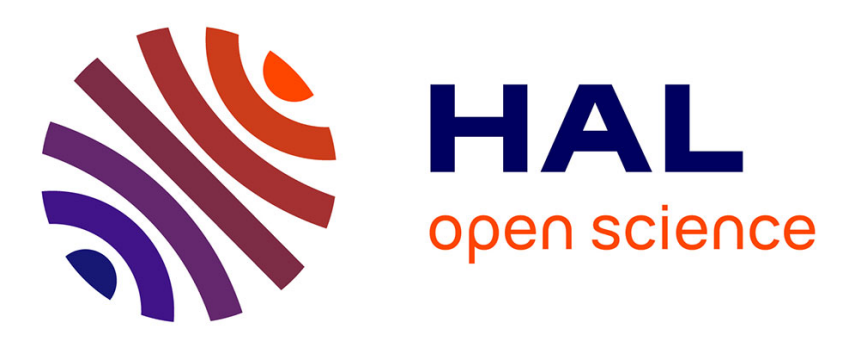

\title{
In vivo Performance of Biodegradable Calcium Phosphate Glass Ceramics using the Rabbit Model: Histological and SEM Observation
}

\author{
A. G. Dias, M. A. Lopes, J. D. Santos, A. Afonso, K. Tsuru, A. Osaka, S. \\ Hayakawa, S. Takashima, Y. Kurabayashi
}

\section{To cite this version:}

A. G. Dias, M. A. Lopes, J. D. Santos, A. Afonso, K. Tsuru, et al.. In vivo Performance of Biodegradable Calcium Phosphate Glass Ceramics using the Rabbit Model: Histological and SEM Observation. Journal of Biomaterials Applications, 2006, 20 (3), pp.253-266. 10.1177/0885328206052466 . hal00570764

\section{HAL Id: hal-00570764 \\ https://hal.science/hal-00570764}

Submitted on 1 Mar 2011

HAL is a multi-disciplinary open access archive for the deposit and dissemination of scientific research documents, whether they are published or not. The documents may come from teaching and research institutions in France or abroad, or from public or private research centers.
L'archive ouverte pluridisciplinaire HAL, est destinée au dépôt et à la diffusion de documents scientifiques de niveau recherche, publiés ou non, émanant des établissements d'enseignement et de recherche français ou étrangers, des laboratoires publics ou privés. 


\title{
In vivo Performance of Biodegradable Calcium Phosphate Glass Ceramics using the Rabbit Model: Histological and SEM Observation
}

\author{
A. G. Dias, M. A. LOPES AND J. D. SANTOS* \\ Instituto de Engenharia Biomédica (INEB), Laboratório de Biomateriais, \\ Rua do Campo Alegre, 823, 4150-180 Porto, Portugal \\ Universidade do Porto, Faculdade de Engenharia, \\ Departamento de Engenharia Metalúrgica e Materiais, \\ Rua Dr. Roberto Frias, 4200-465 Porto, Portugal \\ A. AFONSO \\ Faculdade de Medicina Dentária da Universidade do Porto (FMDUP) \\ Rua Dr. Manuel Pereira da Silva, 4200 Porto, Portugal \\ K. Tsuru, A. Osaka, S. Hayakawa and S. TAKashima \\ Biomaterials Laboratory, Faculty of Engineering, Okayama University \\ Tsushima, Okayama-Shi 700-8530, Japan \\ Research Center for Biomedical Engineering, Okayama University \\ Tsushima, Okayama-Shi 700-8530, Japan \\ Y. KURABAYASHI \\ Animal Center for Medical Reserch, Okayama University \\ Shikata, Okayama-Shi 700-8530, Japan
}

ABSTRACT: Two MK5 (45CaO-45 $\mathrm{P}_{2} \mathrm{O}_{5}-5 \mathrm{MgO}-5 \mathrm{~K}_{2} \mathrm{O}$, in $\left.\mathrm{mol} \%\right)$ and $\mathrm{MT} 13$ $\left(45 \mathrm{CaO}-37 \mathrm{P}_{2} \mathrm{O}_{5}-5 \mathrm{MgO}-13 \mathrm{TiO}_{2}\right.$, in mol\%) glasses are prepared in the meta- and

\footnotetext{
*Author to whom correspondence should be addressed. E-mail: jdsantos@fe.up.pt
}

JOURNAL OF BIOMATERIALS APPLICATIONS Volume 20 - January 2006 
pyrophosphate regions and crystallized to obtain MK5B and MT13B, respectively. MK5B was obtained by controlled crystallization, and MT13B by powder sintering. As a result of these heat treatment processes, the crystalline phases precipitated in the glassy matrix are $\mathrm{KCa}\left(\mathrm{PO}_{3}\right)_{3}, \beta-\mathrm{Ca}\left(\mathrm{PO}_{3}\right)_{2}$, $\beta$ - $\mathrm{Ca}_{2} \mathrm{P}_{2} \mathrm{O}_{7}$ and $\mathrm{Ca}_{4} \mathrm{P}_{6} \mathrm{O}_{19}$ phases for MK5B and $\mathrm{CaTi}_{4}\left(\mathrm{PO}_{4}\right)_{6}, \mathrm{TiP}_{2} \mathrm{O}_{7}, \alpha$ - and $\beta$ - $\mathrm{Ca}_{2} \mathrm{P}_{2} \mathrm{O}_{7}$ phases for MT13B. To assess the in vivo biological behavior of these glass ceramics, a mixed granulometry in the range $250-355 \mu \mathrm{m}$ and $355-425 \mu \mathrm{m}$ with a ratio of $1 / 1$ was implanted for 2,4 , and 12 weeks in the tibiae of Japanese white rabbits. The results showed that the in vivo behavior was strongly affected by their solubility. All implanted materials, MK5B and MT13B, and $\beta$-tricalcium phosphate ( $\beta$-TCP) as control material, showed signs of degradation in vivo. However, the levels of degradation were quite different throughout the implantation periods. The highest degradation was observed for MK5B glass ceramic and the lowest for MT13B with $\beta$-TCP in-between. All implanted materials allow for new bone formation in the bone defect area. At the longest implantation period (12 weeks), the MT13B and $\beta$-TCP materials were almost completely surrounded by new bone tissue, whereas MK5B showed some unfilled spaces. This behavior is discussed in terms of the high degradation observed in previous studies.

KEY WORDS: in vivo testing, biodegradable glass ceramics, calcium phosphates.

\section{INTRODUCTION}

B one defects occur in a wide range of clinical situations, namely loss of bone substance due to congenital, tumoral, or traumatic reasons. For a long time, the gold standard to repair bone defects was the use of autografts and allografts [1,2]. However, these bone grafts present some drawbacks associated with the transplantation procedure. Autografts have inherent limitations, such as availability, blood loss, and post-operative pain whereas in allografts there is a possibility of potential infection. In order to overcome these problems various synthetic grafts have been developed to provide an alternative [3-5]. The ideal bone graft should be osteoconductive so that it allows rapid integration with the host bone. Furthermore, it should be biodegradable at an ideal rate to be replaced by newly formed natural bone, and ultimately osteoinductive to allow rapid new bone formation [6,7].

Calcium phosphate materials are one of the currently used bone grafts due to their similarity to the mineral phase of bone, and excellent osteoconductivity. However, most of the available bone grafts degrade slowly [8-10]. Calcium phosphate glass ceramic materials with polyphosphate structures (chain-like) seem to be a good choice to 
prepare biomaterials with controlled biodegradation. Polyphosphate glasses build a network consisting of two bridging oxygen, one $\mathrm{P}=\mathrm{O}$ double bond, and one non-bridging oxygen per tetrahedron. The bridging oxygen atoms in the network form potential centers for hydrolysis. Depending on the processing parameters used as well as the chemical composition, different amorphous phosphate glasses or crystalline structures can be produced, allowing more or less degradable materials to be prepared [11,12].

Biological evaluations are needed when the final purpose is the implantation of the developed materials in the human body. In vitro and in vivo tests are crucial to obtain an accurate general description of several properties, e.g., biocompatibility, bioactivity, and osteointegration potential. The in vivo animal models act as a link between in vitro studies and clinical trials as they provide information about more effective clinical treatments for injuries. However, the choice of animal models to evaluate bone replacement materials involves several decisions regarding costs, the point of development, and the application of the biomaterial. The investigation of a new biomaterial should begin with a small animal, preferably a rodent model. Thereafter, the evaluation is continued on a higher animal model whose bone physiology more closely resemble that of humans $[13,14]$.

Two calcium phosphate glass ceramics with distinct in vitro acellular degradation rates were previously developed by our team using appropriate heat treatment and composition of a mother glass that led to the precipitation of degradable phases in the meta-, pyro-, and orthophosphate regions [15-18]. The purpose of this work was to complement the physicochemical characterization and in vitro degradation studies previously done with the assessment of the in vivo biological behavior for the use in clinical applications of bone regeneration.

\section{MATERIALS AND METHODS}

\section{Materials Preparation}

The glass ceramics were prepared as described in the previous studies [15,18]. Briefly, MK5B (45CaO-45 $\mathrm{P}_{2} \mathrm{O}_{5}-5 \mathrm{MgO}-5 \mathrm{~K}_{2} \mathrm{O}$, in mol\%) and $\mathrm{MT} 13 \mathrm{~B}\left(45 \mathrm{CaO}-37 \mathrm{P}_{2} \mathrm{O}_{5}-5 \mathrm{MgO}-13 \mathrm{TiO}_{2}\right.$, in mol\%) were prepared by controlled crystallization and powder sintering technique, respectively. MK5B was obtained using a two-step heat treatment of nucleation at $575^{\circ} \mathrm{C}$ for $24 \mathrm{~h}$ followed by crystal growth at $690^{\circ} \mathrm{C}$ for $48 \mathrm{~h}$. MT13B was sintered at $703^{\circ} \mathrm{C}$ for $1 \mathrm{~h}$, with a heating rate of $4^{\circ} \mathrm{C} / \mathrm{min}$. 
Phase pure $\beta$-tricalcium phosphate $(\beta$-TCP) ceramic was used as a control material and was obtained by sintering commercial $\beta$-TCP (Plasma Biotal Limited) heated at a rate of $4^{\circ} \mathrm{C} / \mathrm{min}$ to $1000^{\circ} \mathrm{C}$ and kept at this temperature for $1 \mathrm{~h}$.

The samples for implantation were made into granules with sizes in the range of $250-355$ and $355-425 \mu \mathrm{m}$, using standard milling and sieving techniques. A week before implantation, glass ceramic samples were sterilized using ethylene oxide.

\section{In vivo Implantation Procedure}

The implantation procedure was carried out at the Department of Animal Resources, Okayama University Advanced Science Research Center. A total of 24 Japanese white male rabbits were used in the study. One implant material was placed bilaterally in the tibiae of each rabbit. A mixed granulometry in the range 250-355 and $355-425 \mu \mathrm{m}$ with a weight ratio of $1 / 1$ were implanted for 2,4 , and 12 weeks. General anesthesia was given using 2-3\% sevoflurane inhalation and intravenous injection of pentobarbital sodium solution, and local anesthesia was administered using 1\% lidocaine solution. All surgeries were performed under aseptic conditions. Incision sites were shaved, cleaned, and disinfected. A longitudinal incision was made on the anterior surface, extending from about $10 \mathrm{~mm}$ below the knee joint to a distance of $25 \mathrm{~mm}$. Holes of $4 \mathrm{~mm}$ diameter were drilled using a twist drill machine (Nobel Biocare - SDSC 268/0) through the cortex and into the bone medulla accompanied by simultaneous washing with a physiological saline solution. Later, the holes were filled with glass ceramic granules and subsequently the periosteum and skin were closed in layers. After implantation periods of 2, 4, and 12 weeks, the rabbits were sacrificed by making them inhale isoflurane. The tibiae were removed and all the soft tissue stripped from the bones, the segments of tibiae containing implants were sawed out.

\section{Histological Evaluation}

After removal, the implants were immediately fixed in a neutral formaldehyde fixative solution (6\%) for 7 days. Then the samples were dehydrated using graded series of ethanol solutions and embedded in methylmethacrylate resin (Merck). The implants were cut perpendicular to the tibiae axis in thin slices $(150 \mu \mathrm{m})$ using a diamond blade microtome (Struers Accutom). The obtained slices were then 
polished (Struers Rotopol-1) down to $\approx 70-80 \mu \mathrm{m}$. For scanning electron microscopy (SEM) unstained slices were coated with a layer of gold $(\mathrm{Au})$ using a Fine Ion Sputter (JEOL JFC-1100). Elemental analysis was performed using energy dispersive X-ray microanalysis (EDX - NORAN VOYAGER) in association with JEOL JSM-6301F microscope. For histological observations, non-decalcified slices were stained with hematoxylin-eosin and Solo-Chrome R, and examined under a standard light microscope.

\section{RESULTS}

Previously published $[15,17,18]$ X-ray diffraction results showed that MT13B and MK5B glass ceramics were composed of several crystalline phases as shown in Table 1 . Some of these phases, $\beta$-Ca ${ }_{2} \mathrm{P}_{2} \mathrm{O}_{7}$ and $\mathrm{CaTi}_{4}\left(\mathrm{PO}_{4}\right)_{6}$ have already been reported to behave well in vivo, showing absence of signs of inflammation and supporting resorption and bone growth $[19,20]$.

During all periods of implantation, MT13B and MK5B were well tolerated with no signs of rejection, infection, or fibrosis. Figure 1 compares the new bone formation process at the shortest ( 2 weeks) and longest (12 weeks) implantation period. The obtained results showed a distinct behavior in the bone response among the implanted materials, MK5B, MT13B, and $\beta$-TCP. After the 2-week implantation period, scanning electron micrographs showed that a new bone had formed in the bone defect area for all the implanted materials (Figure 1A, C, and E). However, qualitatively it is clear that bone formation apposed on the MT13B and $\beta$-TCP granules was higher than that found for MK5B, most probably due to the high degradation rate of this material. This difference in behavior was also observed at 12 weeks, although the amount of bone surrounding the implanted materials increased significantly with the time of implantation (Figure 1B, D, and F).

Table 1. Phase quantification by X-ray diffraction $[15,17,18]$.

\begin{tabular}{|c|c|c|c|}
\hline \multicolumn{2}{|l|}{ MK5B } & \multicolumn{2}{|c|}{ MT13B } \\
\hline Phases & $\mathrm{Wt} \%$ & Phases & Wt\% \\
\hline$\beta-\mathrm{Ca}_{2} \mathrm{P}_{2} \mathrm{O}_{7}$ & 73.0 & $\beta-\mathrm{Ca}_{2} \mathrm{P}_{2} \mathrm{O}_{7}$ & 25.5 \\
\hline $\mathrm{KCa}\left(\mathrm{PO}_{3}\right)_{3}$ & 7.0 & $\alpha-\mathrm{Ca}_{2} \mathrm{P}_{2} \mathrm{O}_{7}$ & 26.5 \\
\hline$\beta-\mathrm{Ca}\left(\mathrm{PO}_{3}\right)_{2}$ & 18.0 & $\mathrm{CaTi}_{4}\left(\mathrm{PO}_{4}\right)_{6}$ & 23.4 \\
\hline $\mathrm{Ca}_{4} \mathrm{P}_{6} \mathrm{O}_{19}$ & 2.0 & $\mathrm{TiP}_{2} \mathrm{O}_{7}$ & 24.6 \\
\hline
\end{tabular}



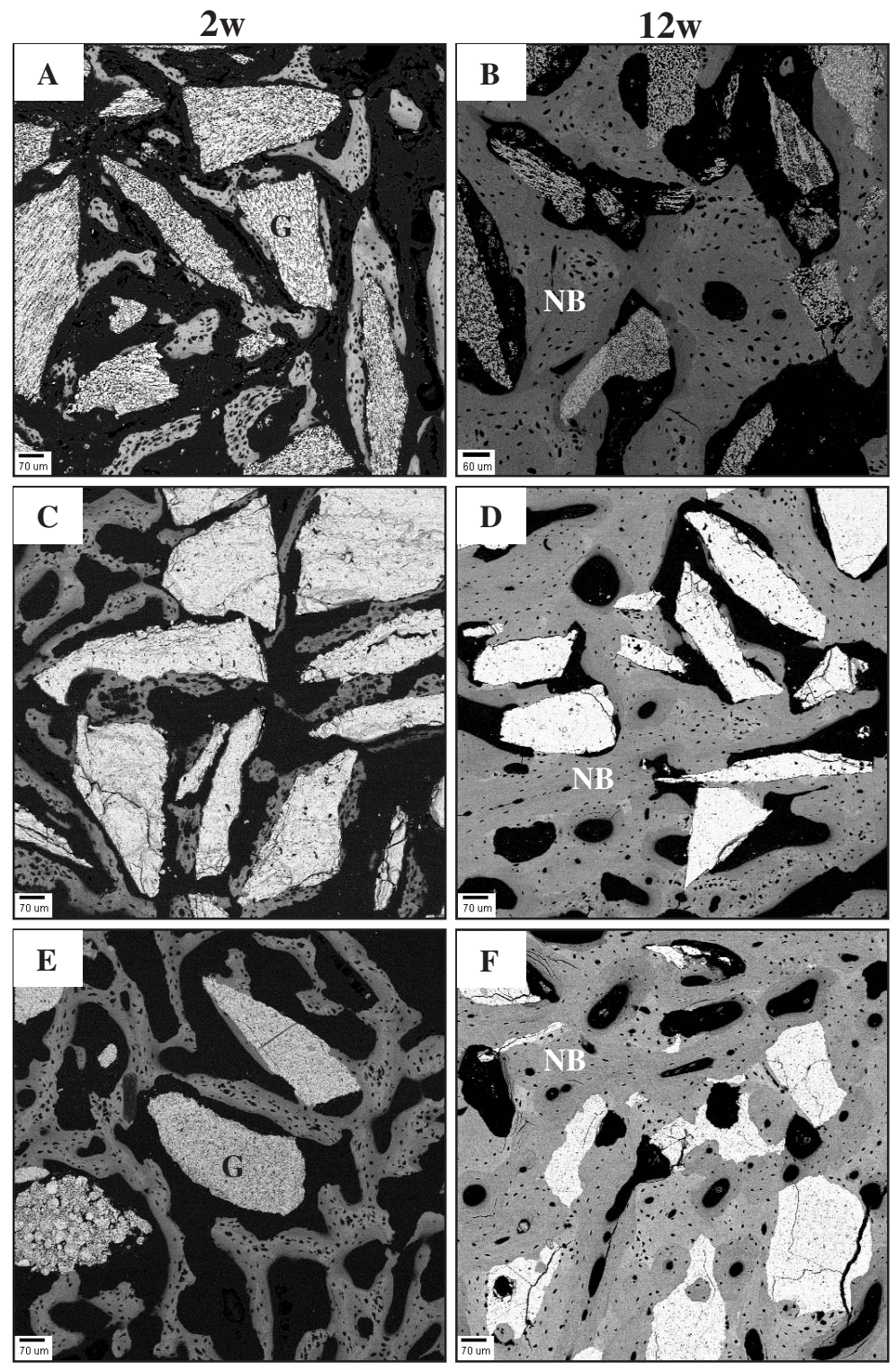

Figure 1. Representative SEM backscattered images of new bone formation after 2 and 12 weeks implantation period: $\operatorname{MK} 5 \mathrm{~B}(\mathrm{~A}, \mathrm{~B}), \mathrm{MT} 13 \mathrm{~B}(\mathrm{C}, \mathrm{D})$, and $\beta$-TCP (E, F). $\mathrm{G}$ - implanted granule material and NB - new bone. 

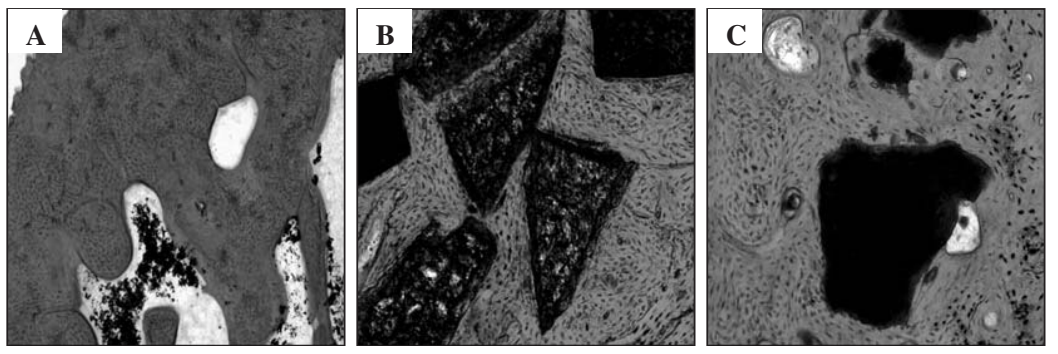

Figure 2. Light microscopy images of MK5B (A), MT13B (B), and $\beta$-TCP (C) materials after 12 weeks implantation time (haematoxylin-eosin staining, magnification $100 \times$ ).

The new bone so formed filled the spaces between the implanted granules and the surface. The MT13B and $\beta$-TCP materials were almost completely surrounded by a new bone tissue after 12 weeks of implantation. The optical microscope images in Figure 2 indicate that at the longest implantation time (12 weeks), a very well organized and vascularized bone was observed for all implanted materials.

Figure 3 shows a representative image of the intermediate implantation period of 4 weeks for all implanted materials. Solo-Chrome R staining allows the visualization of new bone formation with different maturities, i.e., mature bone (MB) well mineralized and immature bone (IB).

Regarding the in vivo degradation process, all implanted materials showed signs of this phenomenon. However, the levels of material degradation were quite different (Figure 4) for the shortest implantation period. On comparing MT13B and $\beta$-TCP materials to MK5B glass ceramic, a marked surface degradation was already observed at 2 weeks for the latter. This difference in the degradation behavior was seen throughout the entire implantation period ( 4 and 12 weeks) for MK5B material, while for MT13B and $\beta$-TCP materials, this behavior was less pronounced.

The degradation pattern of the MK5B glass ceramic in the in vivo experiment confirmed the previous results obtained in in vitro studies [15]. The degradation started with the dissolution of the most soluble phase $\mathrm{KCa}\left(\mathrm{PO}_{3}\right)_{3}$ and the glassy phase that remained, as confirmed by the EDS spectra of Figure 4. The phases denoted by 1 and 2 contained only $\mathrm{Ca}$ and $\mathrm{P}$ elements, but showed different $\mathrm{Ca} / \mathrm{P}$ ratio. The areas denoted by 1 correspond to $\beta-\mathrm{Ca}_{2} \mathrm{P}_{2} \mathrm{O}_{7}$, since the atomic ratio was $\cong 1$. The areas denoted by 2 correspond to $\beta$ - $\mathrm{Ca}\left(\mathrm{PO}_{3}\right)_{2}$ and/or $\mathrm{Ca}_{4} \mathrm{P}_{6} \mathrm{O}_{19}$ since the atomic ratio was $\cong 0.50-0.67$. Thus $\mathrm{KCa}\left(\mathrm{PO}_{3}\right)_{3}$ 

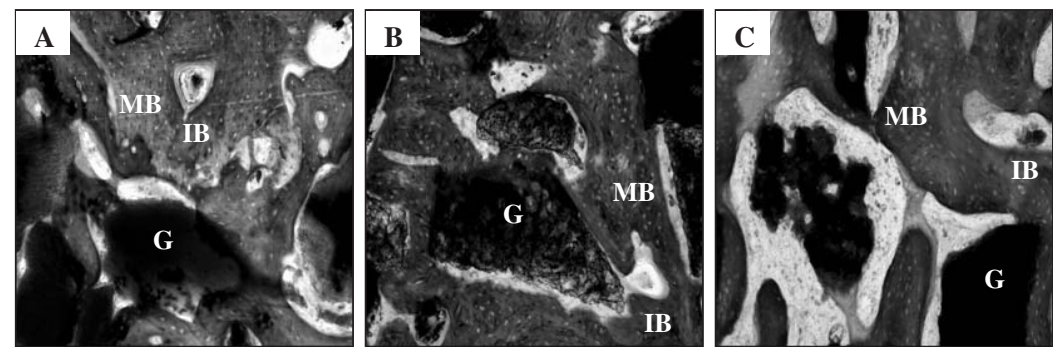

Figure 3. Light microscopy images of MK5B (A), MT13B (B), and $\beta$-TCP (C) granules after 4 weeks at the bone defect area, MB - mature, and IB - immature bone (SoloChrome R staining, magnification $100 \times$ ).

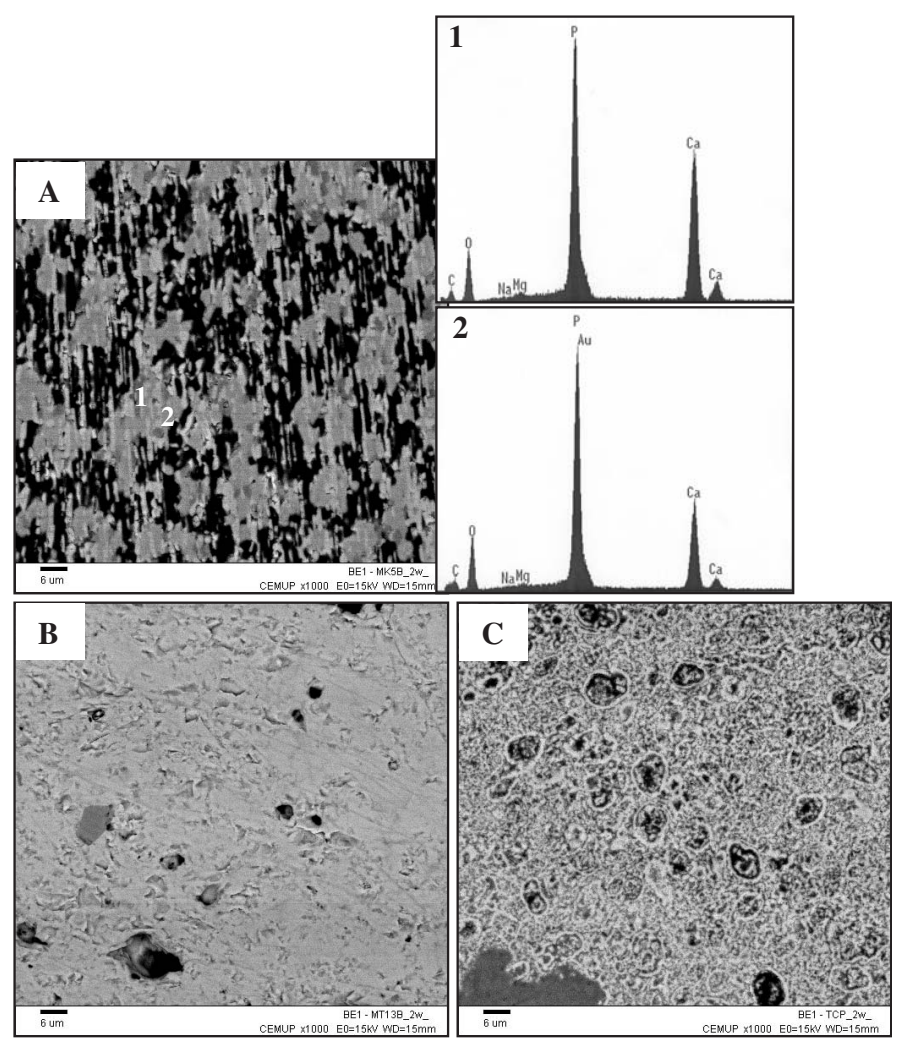

Figure 4. SEM images of MK5B (A), MT13B (B), and $\beta$-TCP (C) materials after 2 weeks implantation time. EDS spectra of the labeled regions $(1,2)$. 

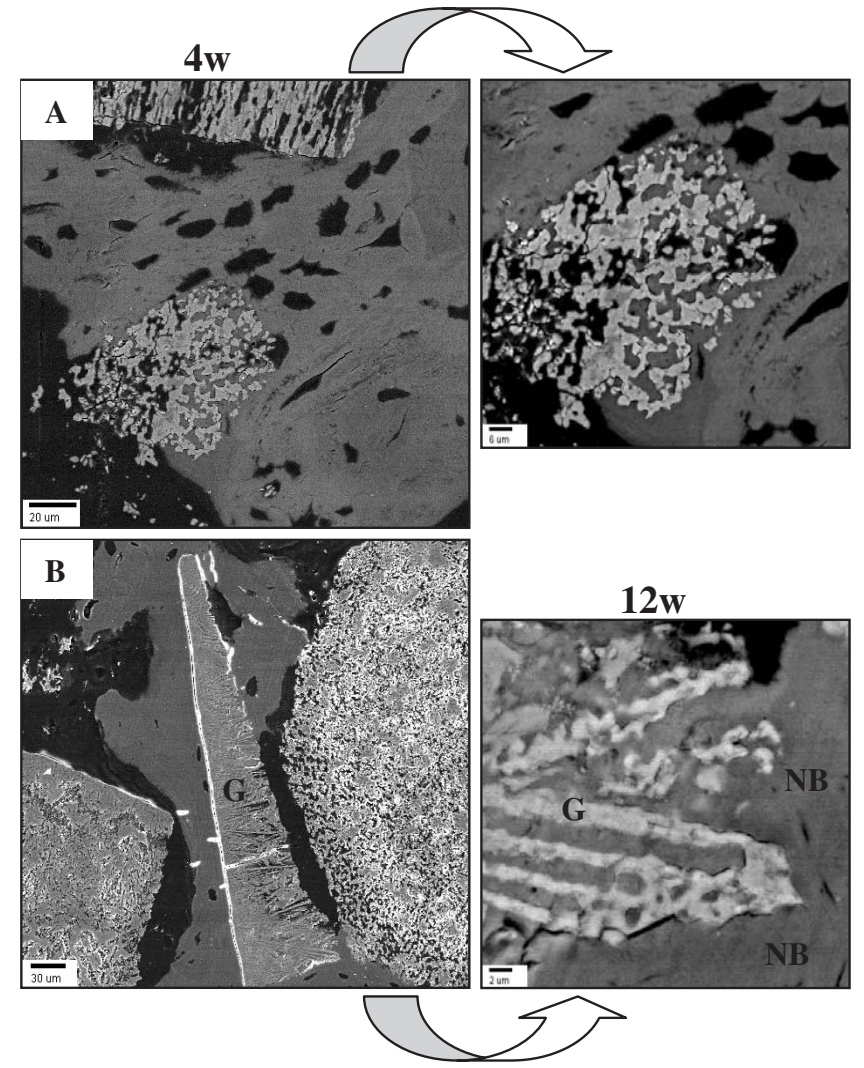

Figure 5. Backscattered images of MK5B granules (G), after 4 and 12 weeks implantation period. New bone (NB) interface showing sites of biodegradation with new bone ingrowth (arrows) in the degraded areas of MK5B glass ceramic.

appeared to be the most degraded phase. After the 4-week implantation period, extensive degradation was already observed for MK5B glass ceramic with the ingrowth of new bone into the structure of the degraded material, Figure 5A. This effect was also observed for the latest implantation period (12 weeks), as shown in Figure 5B.

\section{DISCUSSION}

Despite the fact that all implanted materials underwent some form of biodegradation, the intensity of this phenomenon differed. The highest degradation was observed for MK5B glass ceramic, the lowest for MT13B, and $\beta$-TCP ranked in-between. These results suggested that the 
differences in the in vivo degradation behavior might be attributed to compositional features of the materials. The microstructure of MK5B and MT13B glass ceramics is composed of four crystalline phases, as shown by previous studies $[15,17,18]$. Some of these phases, $\mathrm{KCa}\left(\mathrm{PO}_{3}\right)_{3}$, $\beta$-Ca $\left(\mathrm{PO}_{3}\right)_{2}$, and $\mathrm{Ca}_{2} \mathrm{P}_{2} \mathrm{O}_{7}$, are known to be quite soluble in physiological conditions, which explains the in vivo response of MK5B [21-23]. TCP is known to be a degradable calcium phosphate phase [24,25], and previous in vivo studies demonstrated that TCP supports resorption and bone growth [26,27]. As this material is now widely used as a synthetic bone graft, it was chosen as a reference material.

The literature reports two different in vivo biodegradation pathways for calcium phosphate biomaterials: one involves solution-mediated processes (implant solubility in physiologic solutions), whereas the other involves a cell-mediated process (two main cell mechanisms are implicated: phagocytosis by macrophages or multinucleated giant cells and resorption by osteoclasts). The mechanism of biodegradation for calcium phosphate ceramics exhibiting high strength is reported to be mainly governed by extracellular fluids. On the other hand, the cellularmediated process is associated with the particle formation due to the disintegration/degradation of the material into small particles. When the macrophages or giant multinucleated cells find these particles, they get activated for endocytosis. If the particle has the adequate size, the cell will attach and the endocytosis process will start. If the particle is too large to be phagocytosed the cells are capable of sealing off a part of a particle, creating a microenvironment between the plasma membrane and the implant material that may retard bone formation [24,28-31].

The MT13B and $\beta$-TCP materials, seemed to behave in a similar way in the in vivo experiment, being the ceramic granules progressively integrated into the newly formed bone with simultaneous solutionmediated degradation process of limited extension.

The biodegradable behavior observed for the MK5B glass ceramic may have occurred by a mixture of the two ways described here. In the first step, the extracellular fluid may dissolve the most soluble phase and the remaining glassy phase, which can then lead to the release of small particles of adequate size to allow cell-mediated elimination. This hypothesis is currently under study using further implantation testing.

In all micrographs, the morphology of MK5B glass ceramic suggested that it was unstable in the biological environment probably due to a high surface degradation rate. Several effects, such as the concentration of dissolved calcium and phosphate ions into the physiological medium and the $\mathrm{pH}$ changes are associated with the instability of ceramics when in contact with biological fluids. 
As shown in the in vitro studies previously reported, the level of degradation observed for MK5B glass ceramic is well above that reported in the literature for bioactive ceramics, namely TCP and hydroxyapatite [15,32]. Previous degradation studies, performed in Tris-HCl buffer solution during 6 weeks with a mixing speed of $120 \mathrm{rpm}$, led to the following ion release levels: calcium ranging from $168-387 \mathrm{ppm}$ to $387-163 \mathrm{ppm}$, phosphorus and potassium constantly increasing from 387 to $1618 \mathrm{ppm}$ and from 261 to 1134, respectively, and decreasing to a more acidic $\mathrm{pH}(7.40-6.01)$.

Over the duration of the implantation period, the surface areas of the implanted MK5B granules that had not yet been covered with new bone kept on degrading with associated ion release. This, jointly with the acidic lysosomal content released from inflammatory cells (macrophages and/or multinucleated giant cells) that initially migrated to the defect area, contributed to the local decrease of $\mathrm{pH}$ and therefore speeded up the degradation process previously expected from this material.

Due to the multiphase microstructure, implanted granules seemed to be eroded instead of being completely disintegrated into small particles that can be ingested, and therefore might be sealed off by macrophages. Meanwhile, the cells of osteogenic potential keep migrating to the defect area among implanted granules and begin to make new bone by appositional growth. The formation of an entrapped pool of eroded material and released metabolites seemed to have happened due to the de novo bone formation by osteoconduction. This occurrence is likely to be temporary as in vivo is a dynamic system, where the local chemistry is buffered by the continuous circulation of the body fluids. Future work focused on longer implantation times is required to evaluate this hypothesis.

Eventhough a high degradation rate was observed for MK5B, no evidence for the presence of fibrous tissue was found for the longer implantation periods. An osteoid matrix was observed in the neighborhoods of the degraded granules, which is a sign of the natural process of bone formation.

The sustained osteointegration of the glass ceramics under study as well as the absence of any signs of inflammation or osteolytic reaction will merit further studies with these promising bone grafts.

\section{CONCLUSIONS}

MK5B and MT13B glass ceramics have distinct in vivo degradation behavior, but both materials were found to be very osteoconductive in 
a rabbit model. Hence, they have good prospects to be clinically applied instead of the currently used $\beta$-TCP and HA bone grafts materials.

\section{ACKNOWLEDGMENTS}

The authors would like to thank D. Ana Mota for kindly preparing the samples for histological observation and FCT - Fundação para a Ciência e a Tecnologia for financial support through the $\mathrm{PhD}$ grant PRAXIS XXI/BD/21458/99.

\section{REFERENCES}

1. Parikh, S.N. (2002). Bone Graft Substitutes in Modern Orthopedics, Orthopedics, 25(11): 1301-1309.

2. Tomford, W.W. (2000). Bone Allografts: Past, Present and Future, Cell and Tissue Banking, 1: 105-109.

3. Betz, R.R. (2002). Limitations of Autograft and Allograft: New Synthetic Solutions, Orthopedics, 25(5): S561-S570.

4. Lane, J.M., Tomin, E. and Bostrom, M.P.G. (1999). Biosynthetic Bone Grafting, Clinical Orthopaedics and Related Research, Supplement S (367): S107-S117.

5. Gazdag, A.R., Lane, J.M., Glaser, D. and Forster, R.A. (1995). Alternatives to Autogenous Bone Graft: Efficacy and Indications, Journal of the American Academy of Orthopaedic Surgeons, 3(1).

6. Vaccaro, A.R. (2002). The Role of the Osteoconductive Scaffold in Synthetic Bone Grafts, Orthopedics, 25(5): S571-S578.

7. Damien, C.J. and Parsons, J.R. (1991). Bone-Graft and Bone-Graft Substitutes - A Review of Current Technology and Applications, Journal of Applied Biomaterials, 2(3): 187-208.

8. Porter, A.E., Patel, N., Skepper, J.N., Best, S.M. and Bonfield, W. (2003). Comparison of in vivo Dissolution Processes in Hydroxyapatite and Silicon-substituted Hydroxyapatite Bioceramics, Biomaterials, 24(25): 4609-4620.

9. Raynaud, S., Champion, E., Lafon, J.P. and Bernache-Assollant, D. (2002). Calcium Phosphate Apatites with Variable $\mathrm{Ca} / \mathrm{P}$ Atomic Ratio III. Mechanical Properties and Degradation in Solution of Hot Pressed Ceramics, Biomaterials, 23(4): 1081-1089.

10. Klein, C., Wolke, J.G.C., Deblieckhogervorst, J.M.A. and Degroot, K. (1994). Features of Calcium-Phosphate Plasma-Sprayed Coatings - An in-vitro Study, Journal of Biomedical Materials Research, 28(8): 961-967.

11. Brow, R.K. (2000). Review: The Structure of Simple Phosphate Glasses, Journal of Non-Crystalline Solids, 263(1-4): 1-28.

12. Shelby, J.E. (1997). Introduction to Glass Science and Technology, The Royal Society of Chemistry, UK. 
13. Fini, M. and Giardino, R. (2003). In vitro and in vivo Tests for the Biological Evaluation of Candidate Orthopedic Materials: Benefits and Limits, Journal of Applied Biomaterials \& Biomechanics, 1: 155-163.

14. Ratner, B.D., Hoffman, A.S., Schoen, F.J. and Lemons, F.J. (1996). Biomaterials Science: An Introduction to Materials in Medicine, Academic Press.

15. Dias, A.G., Lopes, M.A., Gibson, I.R. and Santos, J.D. (2003). In vitro Degradation Studies of Calcium Phosphate Glass Ceramics Prepared by Controlled Crystallization, Journal of Non-Crystalline Solids, 330(1-3): 81-89.

16. Dias, A.G., Lopes, M.A. and Santos, J.D. (2004). Protein Adsorption Effect on in vitro Acellular Biodegradation of CaO- $\mathrm{P}_{2} \mathrm{O}_{5}$ Glass Ceramics, Advanced Materials Forum, 455-456: 398-401.

17. Dias, A.G., Skakle, J.M.S., Gibson, I.R., Lopes, M.A. and Santos, J.D. (2005). In situ Thermal and Structural Characterization of Bioactive Calcium Phosphate Glass Ceramics Containing $\mathrm{TiO}_{2}$ and $\mathrm{MgO}$ Oxides: HT-XRD Studies, Journal of Non-Crystalline Solids, 351: 810-817.

18. Dias, A.G., Tsuru, K., Hayakawa, T., Lopes, M.A., Santos, J.D. and Osaka, A. (2004). Crystallisation Studies of Biodegradable CaO- $\mathrm{P}_{2} \mathrm{O}_{5}$ Glass with $\mathrm{MgO}$ and $\mathrm{TiO}_{2}$ for Bone Regeneration Applications, Glass Technology, 45(2): 78-79.

19. Gross, U., Muller-Mai, C., Voigt, C., Mesgarian, M., Berger, G. and Ploska, U. (2000). Tissue Response in the Femur of Rabbits after Implantation of a New Calcium Titanium Phosphate Composition, Key Engineering Materials, 192: 383-386.

20. Kitsugi, T., Yamamuro, T., Nakamura, T. and Masanori, O. (1995). Transmission Electron Microscopy Observations at the Interface of Bone and Four Types of Calcium Phosphate Ceramics with Different Calcium/ Phosphorous Molar Ratios, Biomaterials, 16(14): 1101-1107.

21. Chun, S., Jeong, J.H., Kim, K.H. and Kim, S. (2000). Biodegradation Study of Amorphous and Crystalline Calcium Metaphosphate in the SBF and Tris-buffer Solution, Key Engineering Materials, 192: 131-134.

22. Chun, S., Na, S.W., Lee, J.H., Chung, J.P., Ryu, I.C. and Kim, S.Y. (2002). Biodegradation Study of Potassium Calcium Metaphosphate in the SBF and Tris-buffer Solution, Key Engineering Materials, 218: $149-152$.

23. Lin, F.H., Liao, C.J., Chen, K.S., Sun, J.S. and Liu, H.C. (1997). Degradation Behaviour of a New Bioceramic: $\mathrm{Ca}_{2} \mathrm{P}_{2} \mathrm{O}_{7}$ with Addition of $\mathrm{Na}_{4} \mathrm{P}_{2} \mathrm{O}_{7} \cdot 10 \mathrm{H}_{2} \mathrm{O}$, Biomaterials, 18(13): 915-921.

24. Koerten, H.K. and van der Meulen, J. (1999). Degradation of Calcium Phosphate Ceramics, Journal of Biomedical Materials Research, 44(1): 78-86.

25. Kwon, S.H., Jun, Y.K., Hong, S.H. and Kim, H.E. (2003). Synthesis and Dissolution Behavior of Beta-TCP and HA/Beta-TCP Composite Powders, Journal of the European Ceramic Society, 23(7): 1039-1045.

26. Lu, J.X., Gallur, A., Flautre, B., Anselme, K., Descamps, M. and Thierry, B., et al. (1998). Comparative Study of Tissue Reactions to Calcium Phosphate 
Ceramics among Cancellous, Cortical, and Medullar Bone Sites in Rabbits, Journal of Biomedical Materials Research, 42(3): 357-367.

27. Yuan, H.P., De Bruijn, J.D., Li, Y.B., Feng, J.Q., Yang, Z.J., De Groot, K. and Zhang, X.D. (2001). Bone Formation Induced by Calcium Phosphate Ceramics in Soft Tissue of Dogs: A Comparative Study Between Porous $\alpha$-TCP and $\beta$-TCP, Journal of Materials Science-Materials in Medicine, 12(1): $7-13$.

28. Jianxi, Lu, Michel, Descamps, Jacques, Dejou, Gilles, Koubi, Pierre, Hardouin and Jacques, Lemaitre et al. The Biodegradation Mechanism of Calcium Phosphate Biomaterials in Bone, Journal of Biomedical Materials Research (Applied Biomaterials), 63: 408-412.

29. Legeros, R.Z. (1993). Biodegradation and Bioresorption of Calcium Phosphate Ceramics, Clinic Materials, 14: 65-88.

30. Yli-Urpo, H., Vallittu, P.K., Narhi, T.O., Forsback, A.P., Vakiparta, M. (2004). Release of Silica, Calcium, Phosphorus, and Fluoride from Glass Ionomer Cement Containing Bioactive Glass, Journal of Biomaterials Applications, 19(1): 5-20.

31. John, A., Varma, H.K. and Kumari, T.V. (2003). Surface Reactivity of Calcium Phosphate based Ceramics in a Cell Culture System, Journal of Biomaterials Applications, 18(1): 63-78.

32. Dias, A.G., Lopes, M.A., Gibson, I.R., Skakle, J.M.S., Tsuru, K., Hayakawa, S., Osaka, A. and Santos, J.D. In vitro Studies of Calcium Phosphate Glass Ceramic Containing $\mathrm{TiO}_{2}$ and $\mathrm{MgO}$ Ions: Dissolution Behavior (submitted). 